\title{
Szükséges-e a naponkénti rutinmellkasröntgen tüdőresectio után? Bizonyítékalapú döntési taktika
}

\author{
Is daily chest $\mathrm{X}$-ray necessary after lung resection? \\ Secrets of an evidence-based decision
}

\author{
FURÁK JÓZSEF ${ }^{1, @}$, GÉCZI TIBOR ${ }^{1}$, PÉCSY BALÁZS ${ }^{1}$, MORVAY ZITA $^{2}$ \\ Szegedi Tudományegyetem, Szeged, \\ 'Sebészeti Klinika (igazgató: Dr. Lázár György), \\ ${ }^{2}$ Radiológiai Klinika (igazgató: Dr. Palkó András)
}

\begin{abstract}
Bevezetés: A hazai mellkassebészetek jó részében érvényben lévő aranyszabály szerint napi rutinmellkasröntgen- (RTG-) vizsgálat elvégzése javasolt tüdőlobectomia után mindaddig, amíg a betegeknek mellkasi csövük van. Más itthoni centrumokban viszont nem ragaszkodnak ehhez a gyakorlathoz. A szerzők e két szemlélet eredményeit hasonlítják össze osztályuk anyagában. Anyag és módszer: 148 olyan beteget értékeltek, akiknél problémamentes lobectomia és egy mellkasi cső behelyezése történt. A rutinmellkas-RTG-csoportba (R-RTG) 50 beteg tartozik, akiknél közvetlenül a mütét után, valamint a szivás idején naponta rutinszerüen és a cső eltávolítását követő napon szintén mellkas-RTG-felvétel készült. 98 betegnél csak tünetek és/vagy panasz esetén (láz, hypoxia, subcutan emphysema, tartós levegökilépés) és/vagy a mellkasi drain eltávolítását követő napon készült RTG (T-RTG). A következö mủtét utáni adatokat értékelték: láz, kóros RTG kép/lelet (pneumothorax [PTX], folyadék, atelectasia, subcutan emphysema, haematoma), RTG-felvételek száma, drainage-tartam és esetleges új cső behelyezése. Eredmények: Az átlagos drainage-idő 3,7 és 3,8 nap volt az R-RTG-és a T-RTG-csoportokban. A mellkasi cső eltávolítását követően kóros RTG-leletet az R-RTG-csoport betegeinek 50\%-ában $(25 / 50)$ és a T-RTG-csoport 46,9\%-ában (46/98) $(p=0,724)$ kaptak, de új cső behelyezésére az R-RTG-csoportban csak 12\%-ban (3/25), illetve a T-RTG-csoportban csak 15,2\%-ban (7/46) volt szükség. Az elkészített RTG-felvételek száma az R-RTG-csoportban 5,0, míg a T-RTG-csoportban 2,3 volt $(p=0,0001)$. Következtetés: Nem volt több mütét utáni szövődmény és csőeltávolitás utáni kóros RTG-lelet, ha az RTG-felvétel csak a betegek tünetei/panaszai alapján készült a rutinszerü napi RTG-vizsgálatok helyett. A kóros RTG-leleteken jelzett szövődményeknek csak 12-15\%-a igényelt új csőbehelyezést. A tünetek alapján kért RTG-felvételek száma megközelítőleg 50\%-kal csökkenthető.
\end{abstract}

Kulcsszavak: lobectomia, mellkasröntgen, szövődmény

Objectives: The 'gold standard' practice following insertion of a chest tube after lobectomy is daily chest radiography (CXR), but this is not always followed. We compared the outcomes associated with the use of these two methods in our practice. Methods: Data from 148 patients who underwent uncomplicated lobectomies with insertion of one chest drain were analysed. In the routine CXR group (R-CXR) (50 patients), an immediate postoperative CXR, daily routine radiography during the drainage period, and one after surgical drain removal were performed. In the symptomatic CXR group (S-CXR) (98 patients), a CXR was performed only for symptomatic patients (fever, hypoxia, subcutaneous emphysema, air leak) and/or a single radiograph was taken after surgical drain removal. The following postoperative data were compared: fever, CXR abnormalities (pneumothorax, fluid, atelectasis, subcutaneous emphysema, haematoma), number of radiographs, drainage time, and new drain insertion. Results: The mean chest tube duration was 3.7 and 3.8 days in the R-CXR and S-CXR groups, respectively. Abnormal CXRs after surgical drain removal were reported in 50\% $(25 / 50)$ and $46.9 \%(46 / 96)(p=0.724)$ of patients in the R-CXR and S-CXR groups, respectively, but new drain insertion was only necessary in $3 / 25(12 \%)$ and $7 / 46(15.2 \%)$ of these cases. The mean number of CXRs for each patient was 5.0 and 2.3 $(p=0.0001)$ in the R-CXR and S-CXR groups, respectively. Conclusions: If CXRs are limited to symptomatic patients then the number of radiographs can be reduced by around $50 \%$. There were no more postoperative complications or abnormal final CXR findings if the CXR was only ordered for symptomatic patients instead of as 'daily routine' during the postoperative period. Only $12-15 \%$ of the CXR abnormalities required surgical intervention.

Keywords: lobectomy, chest radiographs, complications

Beérkezett: 2013. november 28.; elfogadva: 2014. május 12.

(a) Levelezési cim/Corr. address: Dr. Furák József, Szegedi Tudományegyetem, Sebészeti Klinika, 6701 Szeged, Szőkefalvi-Nagy Béla u. 6., Tel.: +36 30995 5815, E-mail: jfurak@gmail.com 


\section{Bevezetés}

Tüdőlebeny-resectión átesett, mellkasi csővel rendelkező betegeknél a naponkénti úgynevezett rutinmellkas-RTG készitése a legtöbb hazai mellkassebészeti osztályon berögzült gyakorlat. Ezt a helyi szokásokon és nem evidencián alapuló gyakorlatot a nemzetközi szakirodalom megkérdöjelezi. Egyes szerzök hangsúlyozzák, hogy tünetmentes betegeknél ez az eljárás nem szükséges, ${ }^{1}$ míg más adatok szerint a rutin, naponkénti RTG eredménye az eseteknek csak 27\%-ában befolyásolta a beteg közvetlen kezelését. ${ }^{2}$ McKenna eredményeit és gyakorlatát megismerve ${ }^{1}, 2010$-ben változtattunk az addigi szokásainkon és lobectomia után, panaszmentes betegnél, eltekintettünk a rutinmellkas-RTG készitésétől.

Jelen munkánkban azt vizsgáljuk meg, hogy hogyan alakultak a mütét utáni eredmények és szövődmények az említett, két teljesen eltérő RTG-kérési szokás időszakában.

\section{Anyag és módszer}

2010-ben és 2011-ben 148, szövődménymentes lobectomián átesett betegnél 2:1 arányú randomizációt végeztünk, két csoportot alkotva annak alapján, hogy milyen indikációval és gyakorisággal kértünk részükre a mütét utáni időszakban RTG-felvételt.
Ötven beteget (17 férfi, 33 nö) a rutin-RTG-csoportba (R-RTG) soroltunk, akiknél közvetlenül a mütét után, majd a szívókezelés teljes tartama alatt minden nap és végül a csö eltávolitása utáni napon is mellkas-RTG készült.

Kilencvennyolc betegnél ( 44 férfi, 54 nő) nem készitettünk rutinszerüen mellkas-RTG-t a mütét utáni időben. Mellkas-RTG-t csak akkor kértünk, ha a betegnek a drainálás ideje alatt légmellre vagy folyadékra utaló tünete és/vagy panasza volt (T-RTG-csoport), és egy záró RTG készült a cső eltávolítása utáni napon. Röntgenfelvétel készült továbbá, ha a beteg légszomjról panaszkodott, erős fájdalmat jelzett, lázat, hypoxiát, subcutan emphysemát vagy tartós levegőkilépést észleltünk. A röntgenfelvétel kórtermi volt, a beteg ülö állapotában és belégzésben. A betegek adatait az 1. táblázat mutatja. Nem volt szignifikáns eltérés a két csoport betegeinek adatai között a társbetegségek, a mütéti indikációk és a daganat stádiuma tekintetében.

Tanulmányunkban a betegek mütét utáni adatait dolgoztuk fel a beteg osztályról történő elbocsátásáig. Ezek a következők: mellkas-RTG-k száma, kóros eltérések a mellkas-RTG-n (PTX, folyadék, haematoma, subcutan emphysema, atelectasia), drainálási idő hossza, kórházi tartózkodás hossza, új cső behelyezése és a láz előfordulása. A statisztikai feldolgozás SPSS (Chicago, IL, Amerikai Egyesült Államok) programmal történt.

1. táblázat. Betegek adatai

\begin{tabular}{|c|c|c|c|}
\hline & R-RTG-csoport $(n=50)$ & T-RTG-csoport $(n=98)$ & $p$-érték \\
\hline Férfi:nő & $17: 33$ & $44: 54$ & 0,203 \\
\hline Átlagéletkor & $59,9(40-76)$ & $61,0(16-81)$ & \\
\hline Cukorbetegség & $5(10 \%)$ & $7(7,1 \%)$ & 0,547 \\
\hline COPD & $12(24 \%)$ & $35(35,7 \%)$ & 0,148 \\
\hline Tartós anticoagulatio & $11(22 \%)$ & $25(25,5 \%)$ & 0,638 \\
\hline Szívbetegség & $33(66 \%)$ & $68(69,4 \%)$ & 0,675 \\
\hline Jóindulatú elváltozás & $5(10 \%)$ & $7(7,1 \%)$ & 0,547 \\
\hline Metastasis & $5(10 \%)$ & $8(8,2 \%)$ & 0,709 \\
\hline Tüdőrák & $40(80 \%)$ & $83(84,7 \%)$ & 0,471 \\
\hline Stádium IA & $11(27,5 \%)$ & $37(44,6 \%)$ & 0,069 \\
\hline Stádium IB & $14(35 \%)$ & $33(39,8 \%)$ & 0,611 \\
\hline Stádium IIA & $8(20 \%)$ & $4(4,8 \%)$ & 0,008 \\
\hline Stádium IIB & $1(2,5 \%)$ & $2(2,4 \%)$ & 0,976 \\
\hline Stádium IIIA & $6(15 \%)$ & $6(7,2 \%)$ & 0,174 \\
\hline Stádium IIIB & 0 & 0 & \\
\hline Stádium IV & $0(0 \%)$ & $1(1,2 \%)$ & 0,486 \\
\hline Adenocarcinoma & $33(66 \%)$ & $60(61,2 \%)$ & 0,217 \\
\hline Laphámrák & $5(10 \%)$ & $17(17,3 \%)$ & 0,279 \\
\hline Más tüdőrák & $2(4 \%)$ & $6(6,1 \%)$ & 0,589 \\
\hline Felsőlebeny-lobectomia & $33(66 \%)$ & $67(68,4 \%)$ & 0,771 \\
\hline
\end{tabular}

R-RTG = rutinmellkasröntgen; T-RTG = tünetek miatt kért mellkasröntgen; COPD = chronicus obstructiv tüdöbetegség 
Azokat a betegeket, akiknél az említett időszakban a lobectomia valamilyen okból szövődményes volt, kizártuk a vizsgálatból. Nem kerültek be azok sem, akiknél pneumonectomia, bilobectomia, sleeve lobectomia vagy ékresectio történt, illetve akiknél kiterjedt kitapadás miatt leválasztást végeztünk és két csövet helyeztünk a mellüregbe. A tanulmányban részt vevő betegek mindkét csoportban a mütét során egy $\mathrm{Ch}$ 28-as mellkasi csövet kaptak a rekesz feletti kivezetéssel, a midaxillaris vonalban, és mütét utáni ellátásuk hasonló módon történt. Laborvizsgálat rutinszerüen nem készült, postoperativ vérkép sem. Antibiotikumot profilaxisként csak a mütét napján adtunk. Hosszabb ideig kapott a beteg antibiotikumot terápiás szándékkal neoadjuvans kezelés után, ha láza alakult ki vagy atelectasiát észleltünk az RTG-képen.

Mütét előtt, természetes módon, készült mellkas-computertomographia (CT), bronchoscopia és légzésfunkciós vizsgálat, EKG és teljes nagylabor. Tüdörák esetén csontscintigraphia, koponya-CT és szelektált esetekben pozitronemissziós teszt-CT (PET-CT) történt.

\section{Sebészi eljárás}

Minden esetben posterolateralis thoracotomiából történt a feltárás. A rés és a hörgő varrógéppel került ellátásra. Minden betegnél mediastinalis blockdissectiót is végeztünk, eltávolítva az alsó és felsô mediastinalis nyirokcsomókat a zsírral együtt, és eltávolításra kerültek a hilusi nyirokcsomók is. A mellkast egy darab 28 F-es mellkasi cső felett zártuk, majd a mütétet követően a betegek a mellkassebészeti osztályra kerültek. Közvetlenül a mütét utáni szakban a fájdalomcsillapitót epiduralis katéteren, illetve pleuralis kanülön keresztül, vénásan adagoltuk. A cső eltávolítását követően per os fájdalomcsillapításra tértünk át.

\section{Mellkasi cső kezelése}

A mellkasi csövet a mütétet követően -30 vízcm-es fali szivásra helyeztük. A tüdőexpansiót hallgatózással, a levegökilépést vizuális megfigyeléssel (csőbennék, illetve „swinging” jelenség) a reggeli és a délutáni viziten ellenőriztük. Sem digitális, sem mechanikus levegőkilépést jelző rendszert nem alkalmaztunk. A mellkasi csövet akkor tá- volítottuk el, ha levegőkilépést nem észleltünk, illetve, ha a levezetett mellkasi folyadék mennyisége kevesebb volt napi 400 ml-nél. A hét napnál hosszabb ideig tartó levegőkilépést neveztük „tartós levegőkilépésnek”.

\section{Mellkas-RTG indikációja}

Az R-RTG-csoportban mellkas-RTG-t kértünk már közvetlenül a mütét utáni órákban, és ezt követöen minden nap, amíg a mellkas csövezve volt, függetlenül attól, hogy a betegnek voltak-e panaszai vagy sem. Egy záró RTG készült a mellkasi cső eltávolitását követő napon. Ha a záró RTG-n kórosat nem láttunk, akkor további RTG már nem készült.

Ha a betegnek bármiféle panasza vagy fentebb felsorolt tünete alakult ki, vagy a mellkas-RTG eltérést jelzett, akkor az a szakma szabályai szerint került ellátásra. Az atelectasiát antibiotikum adásával és agresszív fizikotherapiával kezeltük (bronchoscopiát egy alkalommal sem kellett végezni), a PTX-et a mütét során behelyezett cső további benntartásával vagy a mellüreg újbóli becsövezésével láttuk el, a mellkasi folyadékot leszívtuk. Ilyen esetekben további mellkas-RTG-k készültek.

A T-RTG-csoportban, ideális esetben, a mütét után csak egy mellkas-RTG készült, egy nappal azt követően, hogy a mellkasi csövet eltávolítottuk. Ha a betegnek a drainálás ideje alatt bármiféle panasza (láz, hypoxia, növekvő subcutan emphysema) lépett fel vagy tartós levegőkilépés alakult ki, mellkas-RTG-t kértünk és az esetleges eltéréseket a jelzetteknek megfelelően kezeltük.

A panaszmentes betegeket, akiknél az RTG semmiféle kórosat nem jelzett, a cső eltávolítása utáni napon engedtük el az osztályról. Ha az RTG kórosat mutatott vagy a betegnek panasza volt, csak a helyzet rendezése után bocsátottuk el.

\section{Eredmények}

A mütét utáni 30 napon belül halálozás nem volt. A mellkasi drainálás időtartama átlagosan 3,7 nap volt az R-RTGés 3,8 nap a T-RTG-csoportban $(p=0,805)$. Tartós levegőkilépést észleltünk az R-RTG-betegek $8 \%$-ánál és a T-RTG-csoport $10 \%$-ában $(p=0,665)$. A betegek átlagos kórházi tartózkodása 6,4 és 6,2 nap volt $(p=0,704)$ a jelzett csoportokban.

2. táblázat. Kóros mellkasröntgenlelet a drain eltávolítása után

\begin{tabular}{lccc}
\hline & R-RTG $(n=50)$ & T-RTG $(n=98)$ & $p$-érték \\
\hline Pneumothorax & $10(20 \%)$ & $20(20,4 \%)$ & 0,953 \\
Folyadék & $12(24 \%)$ & $22(22,4 \%)$ & 0,832 \\
Haematoma & $1(2 \%)$ & $7(7,1 \%)$ & 0,191 \\
Subcutan emphysema & $2(4 \%)$ & $4(4,1 \%)$ & 0,981 \\
Atelectasia & $3(6 \%)$ & $5(5,1 \%)$ & 0,819 \\
\hline
\end{tabular}

$\mathrm{R}-\mathrm{RTG}=$ rutinmellkasröntgen; $\mathrm{T}-\mathrm{RTG}=$ tünetek miatt kért mellkasröntgen 
Kóros eltérést jelzett az RTG a mellkasi cső eltávolítása után az R-RTG-betegek 50\%-ában (25/50) és a T-RTGbetegek 46,9\%-ában $(46 / 96)(p=0,724)$, de a mellkasi cső ismételt behelyezésére csak a kóros esetek 12\%-ában (3/25), illetve 15,2\%-ában (7/46) volt szükség (2. táblázat). A residualis PTX 20\%-a és 30\%-a $(p=0,559)$, a residualis mellkasi folyadék $0 \%$-a és $4,5 \%$-a $(p=0,453)$ igényelt ismételt csőbehelyezést az R-RTG- és a T-RTG-csoportban.

Láz 21,8\%-ban és 27,7\%-ban fordult elö az R-RTG- és a T-RTG-csoportokban.

Multivariáns statisztikai vizsgálat alapján csak a COPD (chronicus obstructiv tüdőbetegség) jelentett szignifikáns rizikót a mütét utáni kóros RTG-eltérés kialakulására, míg a mütét elötti tartós antikoagulálás, a cukorbetegség és a szívbetegség nem volt szignifikáns rizikótényező.

Az R-RTG-csoportban átlagosan 5,0, míg a T-RTG-csoportban csak 2,3 ( $p=0,0001)$ mellkas-RTG készült a mütét utáni szakban.

\section{Megbeszélés}

Egy sebészeti osztály gyakorlatában a régi dogmák megváltoztatása a fejlődés fontos mérföldköve lehet, de magában foglalhatja a kudarc lehetőségét is. A berögzült hazai reflex szerint tüdőmútét után a mellkas-RTG adja a legmegfelelöbb információt a mellkasi statusról. A gyakorlatban a panaszmentes beteg rutinszerüen elkészített RTG-felvétele olykor elsikkad. Általában a panaszos vagy problémás beteg RTG-je után mutat nagyobb érdeklődést a sebész. Egy összefoglaló tanulmány szerint a tünetek miatt készített RTG-k 79\%-a mutat eltérést, míg a rutin-RTG-k csak $40 \%$-án látható kóros. ${ }^{3}$ Hazánkban a tüdömütétet követö postoperativ ellátás gyakorlatát, a mellkasi csövek kezelését említi a nemrégen megjelent mellkassebészeti tankönyv. ${ }^{4}$

Munkánkban azokat a potenciális szövődményeket vizsgáltuk, amelyek RTG-vel jó eséllyel felfedezhetők. Betegeink között a leggyakoribb mütét utáni szövődmény a mellkasi folyadék (23\%), a PTX (20\%) és a haematoma $(5,4 \%)$ volt, de egyik sem fordult elö szignifikánsan gyakrabban, ha nem készült minden nap RTG a panaszmentes betegről. Az irodalomban a residualis PTX előfordulása $9,5 \%$, és ezeknek $29,5 \%$-át kezelték csőcserével. ${ }^{5}$ Gyakorlatunkban a residualis PTX 26,7\%-át kellett ismételten becsövezni, míg a maradék 73,3\% felszívódott. Más adatok szerint a residualis PTX-ek 3\%-át csövezték. ${ }^{6}$
A tüdőresectio utáni időszak fontos jellemzője a mellkasdrainálás tartama és a tartós levegőkilépés hossza, amelyek, mint bizonyítottuk, nem függenek az RTG-készítés gyakoriságától. A magasabb értékek talán annak tudhatók be, hogy osztályunkon nem használunk digitális levegőkilépést mérő monitort és szívórendszert. ${ }^{7}$

Adataink alapján megállapíthatjuk, hogy a naponkénti rutinmellkasröntgen elhagyása után sem volt több mütét utáni szövődmény, nem volt hosszabb mellkasdrainálás és nem végeztünk több mellkasicső-visszahelyezést residualis PTX vagy folyadék miatt sem. Ezzel a gyakorlattal felére csökkent az RTG-felvételek száma és a sugárterhelés is, anélkül, hogy ezzel a szövődmények száma, súlya változott volna.

\section{Irodalomjegyzék}

${ }^{1}$ McKenna RJ, Mahtabifard A, Pickens A, Kusuanco D, Fuller $C B$ : Fast-tracking after video-assisted thoracoscopic surgery lobectomy, segmentectomy, and pneumonectomy. Ann Thorac Surg 2007; 84: 1663-8

${ }^{2}$ Cerfolio RJ, Bryant AS: Daily chest roentgenograms are unnecessary in nonhypoxic patients who have undergone pulmonary resection by thoracotomy. Ann Thorac Surg 2011; 92: 440-4

${ }^{3}$ Sepehripour AH, Farid S, Shah R: Is routine chest radiography indicated following chest drain removal after cardiothoracic surgery? Interact CardioVasc Thorac Surg 2012; 14: 8348

${ }^{4}$ Molnár FT: A pleura betegségei. In: Mellkassebészet a hétköznapi gyakorlatban. Csekeö $A$ (szerk.). Akadémiai Kiadó, Budapest, 2013, 215-37

${ }^{5}$ Misthos P, Kokotsakis J, Konstantinou M, Skottis I, Lioulias $A$ : Postoperative residual pleural spaces: Characteristics and natural history. Asian Cardiovasc Thorac Ann 2007; 15: 54-8

${ }^{6}$ Martin-Ucar AE, Passera E, Vaughan R, Rocco G: Implementation of a user-friendly protocol for interpretation of air-leaks and management of intercostal chest drains after thoracic surgery. Interact CardioVasc Thorac Surg 2003; 2: 251-5

${ }^{7}$ Brunelli A, Salati M, Refai M, Nunzio LD, Xiumé F, Sabbatini A: Evaluation of a new chest tube removal protocol using digital air leak monitoring after lobectomy: A prospective randomised trial. Eur J Cardiothorac Surg 2010; 37: 56-60 